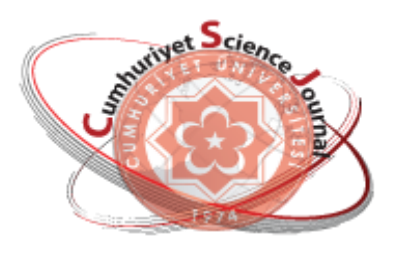

e-ISSN: 2587-246X

ISSN: $2587-2680$

\section{Cumanoriyet Seienee Journal CST}

Cumhuriyet Sci. J., Vol.39-3(2018) 635-641

\title{
Investigation of Radiation Effects on Coffee Beans Using ESR Technique
}

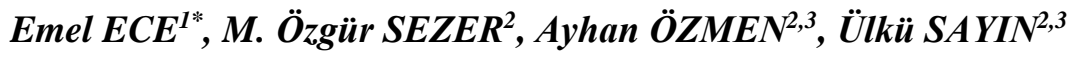 \\ ${ }^{1}$ Karamanoglu Mehmet Bey University., Kamil Ozdag Science Fac., Physics Department., Karaman, TURKEY \\ ${ }^{2}$ Selcuk University, Science Fac., Physics Department., Konya, TURKEY \\ ${ }^{3}$ Selcuk University, Advanced Technology Research and Application Center, Konya, TURKEY \\ Received: 27.02.2018; Accepted: 01.08.2018 \\ http://dx.doi.org/10.17776/csj.399489
}

\begin{abstract}
In this study, radiation effects on coffee beans have been investigated by Electron Spin Resonance (ESR) technique. ESR spectra of natural and irradiated samples at different doses between $0.5 \mathrm{~Gy}$ and $11 \mathrm{kGy}$ by ${ }^{60} \mathrm{Co}$ gamma source were recorded with X-band ESR spectrometer and, radiation dose, ESR microwave power and cavity temperature dependency of paramagnetic centers were investigated. At the results of doseresponse and kinetic studies it was determined that the paramagnetic centers in coffee beans are stable, and sensitive to radiation. Thus, it is shown that the irradiated beans can be used for detection as radiation dosimeter in the investigated dose range.
\end{abstract}

Keywords: Electron Spin Resonance (ESR), coffee beans, irradiation.

\section{Radyasyonun Kahve Çekirdeklerine Etkisinin ESR Tekniği ile İncelenmesi}

Özet. Bu çalışmada kahve çekirdeği üzerine radyasyonun etkisi Elektron Spin Rezonans (ESR) tekniğiyle incelenmiştir. Doğal ve ${ }^{60} \mathrm{Co}$ gama kaynağı ile 0.5 Gy ile $11 \mathrm{kGy}$ doz aralığında farklı dozlarda ışınlanmış örneklerin spektrumları X-band ESR spektrometresiyle kaydedilmiş ve oluşan paramanyetik merkezlerin radyasyona, ESR mikrodalga gücüne ve kavite sıcaklı̆̆ına bağlı değişimleri araştırılmıştır. Doz-cevap ve kinetik çalışmalar sonucunda kahve çekirdeğindeki paramanyetik merkezin radyasyona duyarlı ve kararlı olduğu belirlenmiş, incelenen doz aralığında dozimetrik amaçlı ve ışınlanmış gıda dedeksiyonu için kullanılabilirliği gösterilmiştir.

Anahtar Kelimeler: Elektron Spin Rezonans (ESR), kahve çekirdeği, 1şınlama.

\section{INTRODUCTION}

Electron Spin Resonance (ESR) has been successfully applied to copper salts by Russian physicist Y.K. Zavoisky in 1945 for the first time [1] and, it is the unique spectroscopic method that can be used to examine both organic and inorganic specimens by making it possible to direct determination of the paramagnetic centers in the host material [2].
High-energy radiation can create paramagnetic centers in many substances and the intensity of the paramagnetic centers is proportional to the amount of radiation exposed by the material, i.e., dose of absorption.

Therefore, if radiation (UV, X-ray, $\alpha, \beta, \gamma$ ) sensitive paramagnetic centers are formed in any material and these centers are stable, ESR signals 
of these centers can be used in the measurement of the radiation dose that absorbed.

The ESR dosimetry method is based on the principle of determining the intensity of radicals generated by irradiation in order to determine the amount of absorbed dose by the material, and the materials used for this purpose are called ESR dosimeters.

Because of food products are especially easily accessible, it is very important that they can be used as an ESR dosimeter in the case of radiation accidents $[3,4]$

Irradiation has also been recognized around the world as one of the most effective methods of reducing food production losses, extending shelf life, and ensuring food safety [5-8].

As a result of its social and economic benefits, radiation sterilization has a widespread usage in the world, so in recent years, the volume of irradiated food products on market shelves have been growing steadily.

Although food irradiation is a proven sterilization technique today through scientific works and legal regulations in this area, in order to gain consumer confidence and to facilitate the international trade, it is very important to determine whether the food is irradiated or not, and to determine the absorbed dose in the case of irradiation.

ESR is a powerful spectroscopic technique used in irradiated food detection and in the search of paramagnetic centers created by radiation since it allows direct examination of the paramagnetic centers formed by irradiation and can be applied without harming the organic samples [4, 9-15].

In this study, the effect of irradiation on coffee samples which has an important place in our life was investigated using ESR technique. Radiation sensitivity and stability of the paramagnetic centers induced by irradiation were determined.

\section{MATERIALS AND METHODS}

The coffee beans which were purchased from a local market, cleaned with distilled water and dried at room temperature without exposure to sunlight. Then they were gently grinded with an agate mortar and sieved to have $125-250 \mu \mathrm{m}$ grain sized samples. Finally, the powdered samples were packed in equal mass and irradiated at a radiation dose range of $0.5 \mathrm{kGy}$ to $11 \mathrm{kGy}$ at room temperature using the ${ }^{60} \mathrm{Co}$ irradiation facilities of the Turkish Atomic Energy Authority Sarayköy Nuclear Research and Application Center (SANAEM).

ESR spectra of the both natural and the irradiated samples were recorded at several spectrometer conditions with JEOL JesFa-300X-band ESR spectrometer located in Selcuk University Advanced Technology Research and Application Center ESR Laboratory. Kinetic measurements were done using JEOL liquid nitrogen temperature control unit. The g value of the paramagnetic center was calculated by using $\mathrm{Mn}^{2+}$ signals of the $\mathrm{MgO}$ $\left(\mathrm{Mn}^{2+}\right)$ sample which are used as a standard in JEOL ESR spectrometers.

\section{RESULTS AND DISCUSSION}

In order to determine the magnetic properties of natural coffee beans, firstly, ESR spectra of the non-irradiated powdered samples were recorded at room temperature. As shown in Figure 1, an ESR signal with the $g$ value 2.0047 were observed at the ESR spectrum taken at $1 \mathrm{~mW}$ microwave power and $500 \mathrm{mT}$ magnetic field sweep width. According to this spectrum, naturel coffee beans have paramagnetic structure, also it is seen that there are no signal due to iron oxide or manganese impurities. 


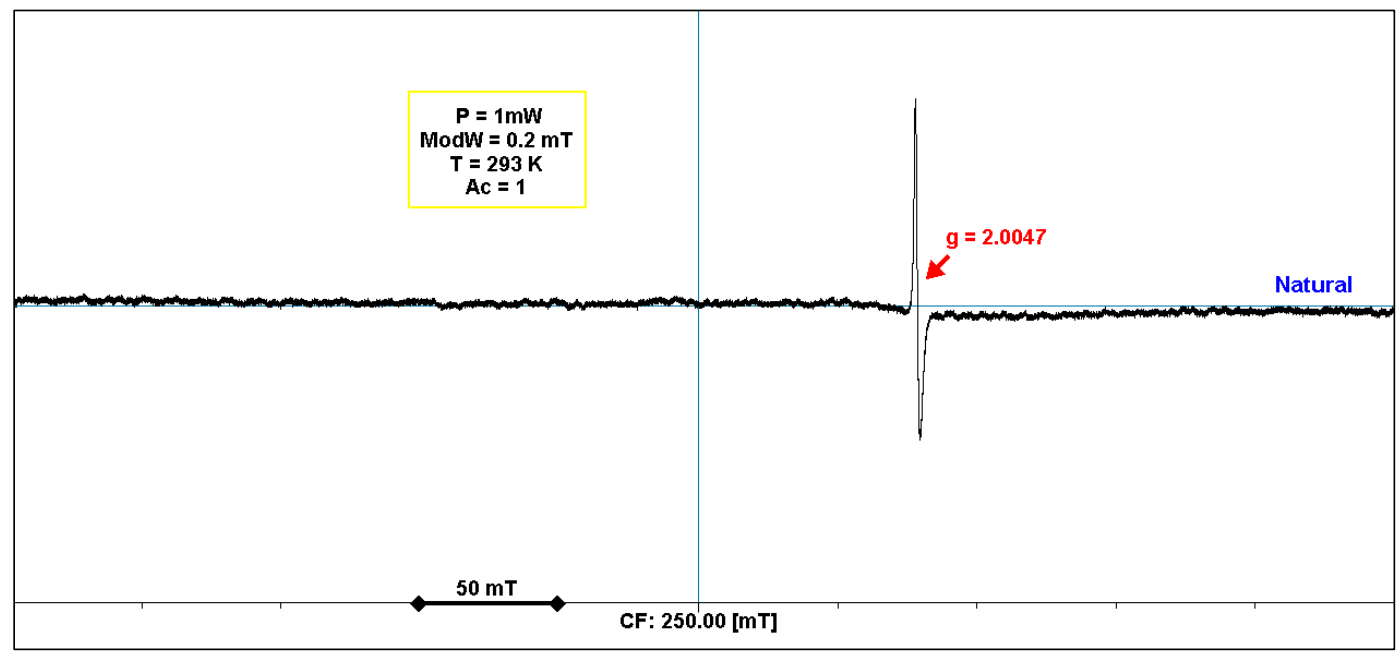

Figure 1. ESR spectra of natural coffee beans recorded at $500 \mathrm{mT}$ sweep width.

In order to investigate the effect of radiation, the powdered samples packed in equal mass were irradiated at a radiation dose range of $0.5 \mathrm{kGy}$ to 11 $\mathrm{kGy}$. The ESR spectra of natural and $5 \mathrm{kGy}$ irradiated samples were given in Figure 2. As can be seen from the spectra, the intensity of $\mathrm{g}=2.0047$ signal increased due to the radiation dose and there is not any other radiation induced signal except this.

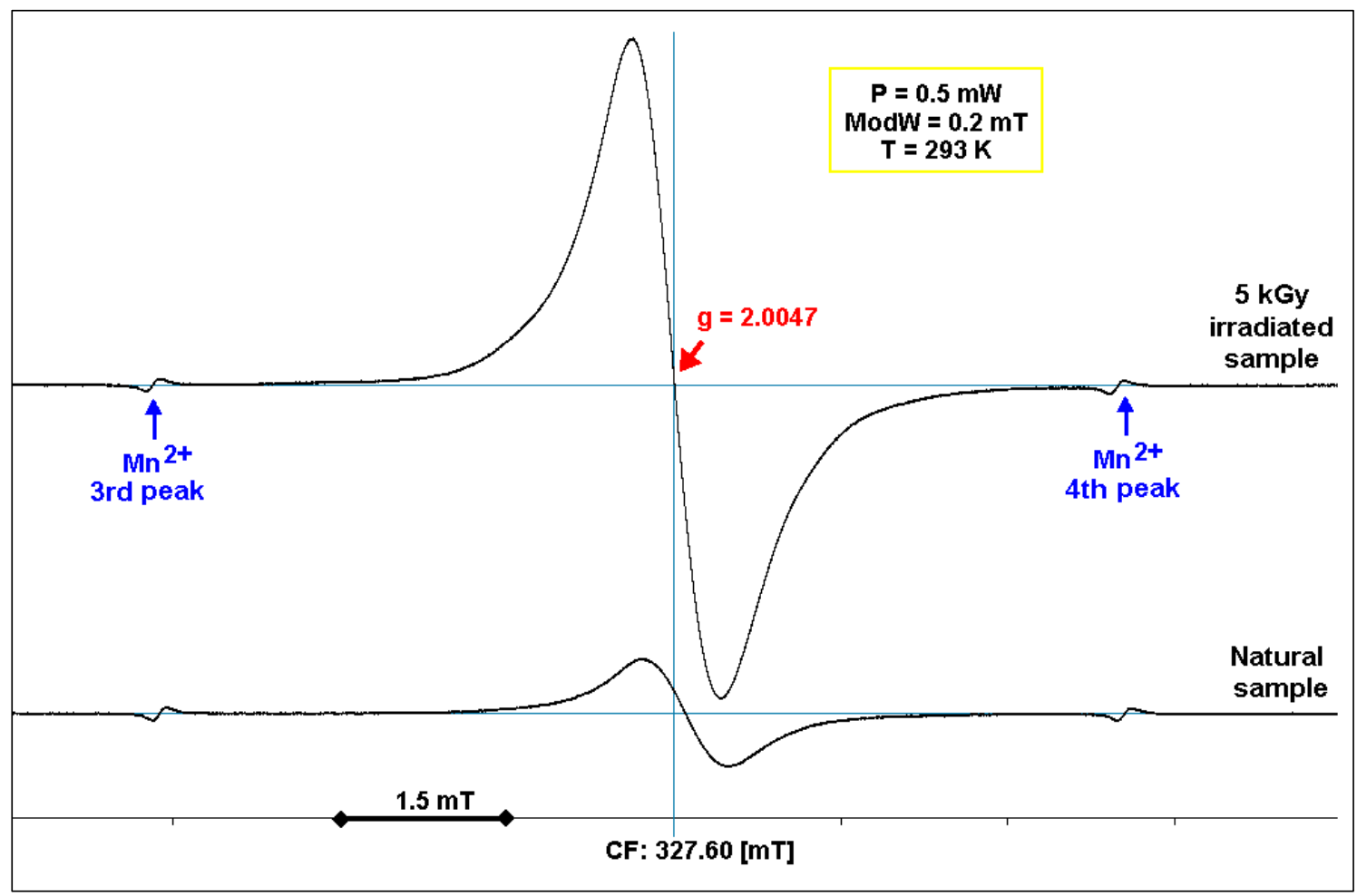

Figure 2. ESR spectra of natural and $5 \mathrm{kGy}$ irradiated coffee bean samples.

In order to observe the changings of these signals due to microwave power and to determine whether they are belongs to same paramagnetic center or not, the ESR spectra of the natural and $11 \mathrm{kGy}$ irradiated samples were recorded at the range of
$0.1 \mathrm{~mW}$ and $4 \mathrm{~mW}$ microwave power and, the graphs of ESR signal intensities were plotted versus square root of microwave power. According to graphs in given Figure 3 the dependence on the microwave power of signal intensities are the same 
for both natural and irradiated samples and the signal intensities increase exponentially between approximately $0.1 \mathrm{~mW}$ and $0.7 \mathrm{~mW}$ powers and saturate at approximately $1 \mathrm{~mW}$ of microwave power.

It has determined that the the $\mathrm{g}=2.0047$ signal which is observed in the natural sample and, of which intensity increased depending on the dose of applied radiation is belong to semiquinone radical observed in cellulose containing foods and known to be sensitive to radiation [4].

In order to determine dependency of signals at ESR spectra of samples to the radiation, they were irradiated between $0.5 \mathrm{kGy}$ and $11 \mathrm{kGy}$ doses and, the spectra were recorded at $0.5 \mathrm{~mW}$ microwave power far from the saturation point and at room temperature. The dose response curve of $g=2.0047$ signal is shown in Figure 4, and the data of this curve is best fitted to $y(x)=y_{0}+a(1-\exp (-b x))$ function where the fit parameters are found as $\mathrm{y}_{0}=453 \pm 70, \mathrm{a}=3824 \pm 240, \mathrm{~b}=0.1743 \pm 0.0249$ with the $\mathrm{R}^{2}=0.99$ correlation coefficient.

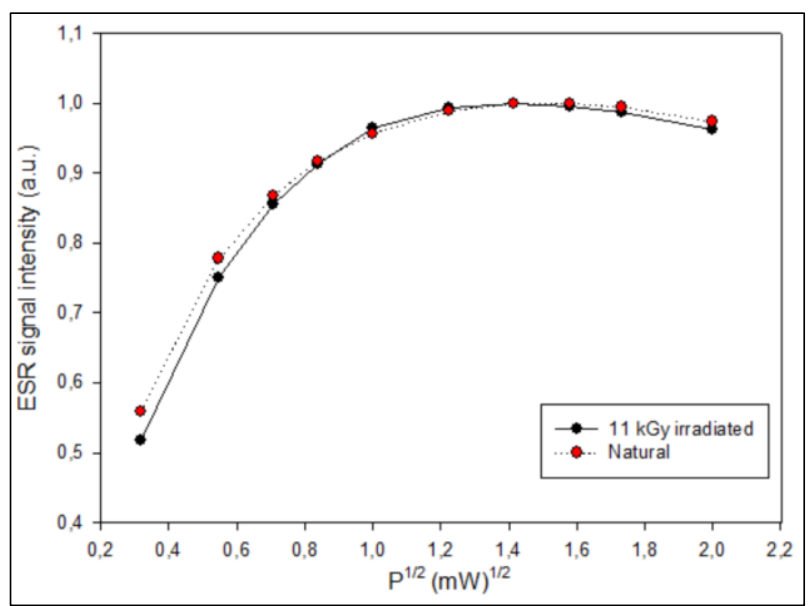

Figure 3. Microwave dependence of $g=2.0047$ signal.

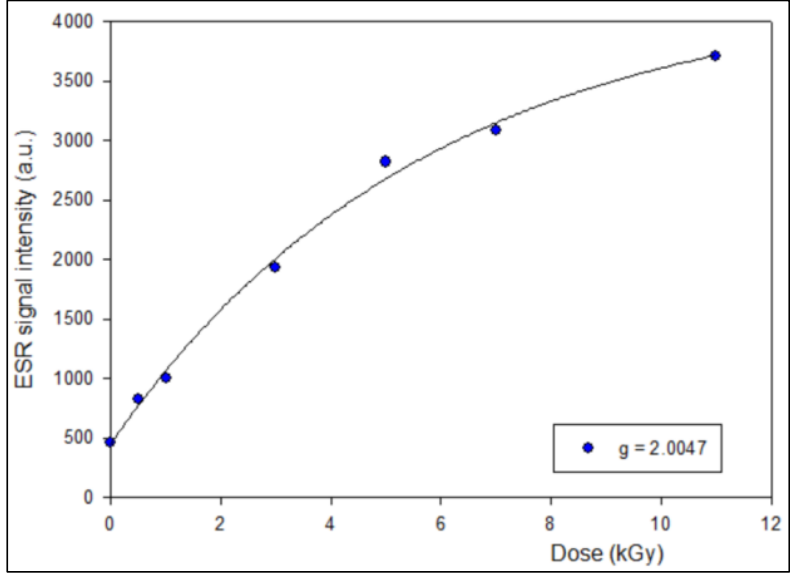

Figure 4. Dose response curve of $\mathrm{g}=2.0047$ signal.

For determining the thermal stability of the radiation sensitive $\mathrm{g}=2.0047$ signal, the ESR spectra of $7 \mathrm{kGy}$ irradiated sample were recorded at $50^{\circ} \mathrm{C}$ spectrometer temperature at intervals of 3-5 minutes up to 65 minutes and, the isotherm curves of these signals for both irradiated and natural samples are given in Figure 5.

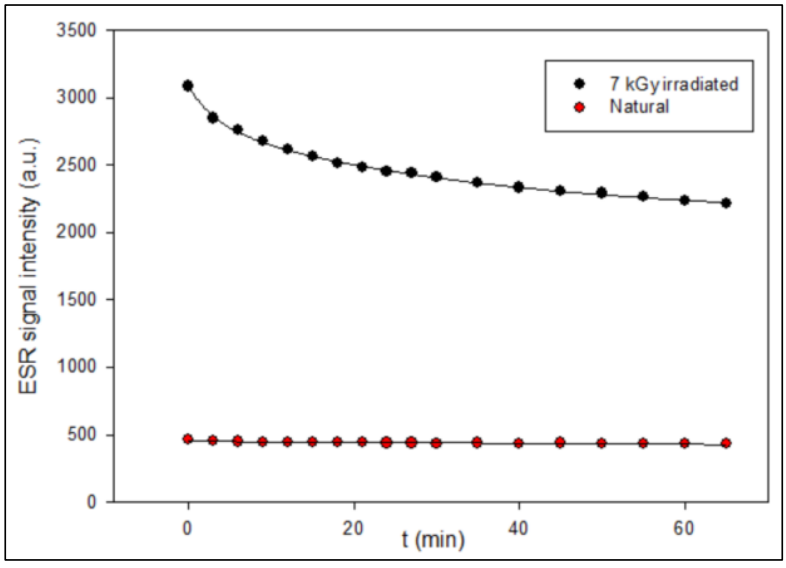

Figure 5. Isothermal annealing curve of $g=2.0047$ signal for natural and irradiated samples at $\mathrm{T}=50{ }^{\circ} \mathrm{C}$ constant temperature.

As clearly seen from the graph given in Figure 5, while the isotherm curve of the natural sample has not changed over time and remained constant, that of the $7 \mathrm{kGy}$ irradiated sample was best fitted to the function shaped $I(t)=I_{01} \exp \left(-k_{1} t\right)+I_{02} \exp \left(-k_{2} t\right)$.

For irradiated specimen fit parameters of isotherm curve function were calculated as; $\mathrm{I}_{01}=447.05 \pm 24.37, \quad \mathrm{k}_{1}=0.1607 \pm 0.0171$, $\mathrm{I}_{02}=2626.07 \pm 23.71, \mathrm{k}_{2}=0.0029 \pm 0.0002$ with the 
correlation coefficient $\mathrm{R}^{2}=0.99$. Here, $\mathrm{I}_{01}$ and $\mathrm{I}_{02}$ are the initial ESR signal intensities of two different paramagnetic centers, and $\mathrm{k}_{1}$ and $\mathrm{k}_{2}$ are the frequency factors of these paramagnetic centers at $50{ }^{\circ} \mathrm{C}$ constant temperature. According to these parameters; it was determined that the investigated signal had two different components with a thermal-life of $\tau_{1}=6.22$ minutes and $\tau_{2}=344.8$ minutes at this temperature.

It becomes definite from the kinetic measurements at $50{ }^{\circ} \mathrm{C}$ that there are an unstable short-lived radical and a stable long-lived radical in the sample. Also, interestingly the isotherm curve behaviors at this temperature for natural and irradiated specimens are different and this is very important both to distinguish the two radicals induced by radiation and to determine if the sample is irradiated or not.

After the annealing process for 65 minutes at $50{ }^{\circ} \mathrm{C}$, the natural and irradiated samples were annealed between $50{ }^{\circ} \mathrm{C}-150{ }^{\circ} \mathrm{C}$ temperatures at $10{ }^{\circ} \mathrm{C}$ intervals for 3 minutes constant time and, ESR spectra of the samples were recorded at each temperature.

The change of $g=2.0047$ signal depending on the temperature is given in Figure 6. According to this graph it has been determined that in the case of 7 $\mathrm{kGy}$ irradiated coffee, the increasing part of the paramagnetic center due to the irradiation effect is completely quenched at $120{ }^{\circ} \mathrm{C}$ temperature, and the intensity of signal is now equal that of natural sample. It was also determined that the signal intensity of the natural sample weakened slightly to $+150{ }^{\circ} \mathrm{C}$, but still does not quench.

Additionally, in order to determine the room temperature stability of the radiation sensitive paramagnetic center with $g=2.0047$, assigned to semiquinone radical, the natural and $5 \mathrm{kGy}$ irradiated specimens were stored at room temperature for 1.5 months and ESR spectra of them were recorded for 2-5 days intervals during this time. The decay curves for room temperature of the signal in natural and irradiated specimens are shown in Figure 7. According to the room temperature kinetics study, it was determined that at the end of 1.5 months, the signal intensity of the $5 \mathrm{kGy}$ irradiated coffee sample decreased by only $36 \%$ of the initial value. As expected, the natural signal has not changed.

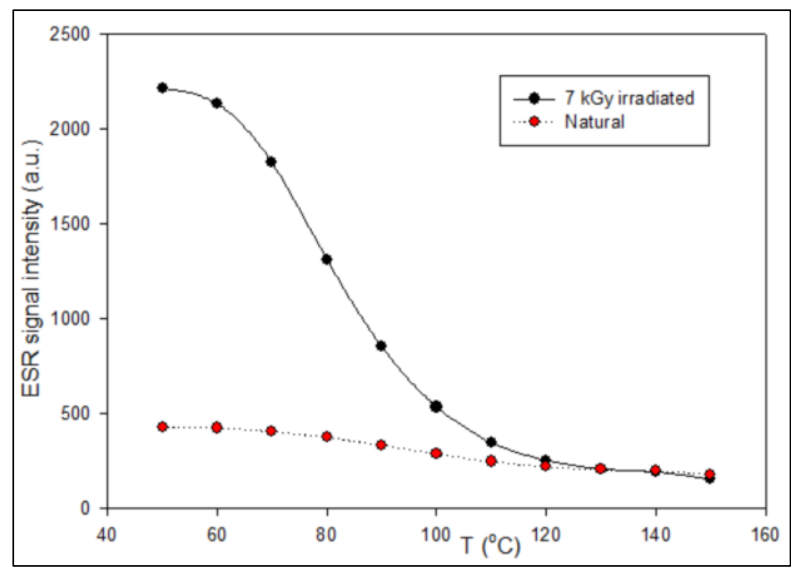

Figure 6. Isochronal annealing curve of $\mathrm{g}=2.0047$ signal for natural and irradiated samples between $\mathrm{T}=50^{\circ} \mathrm{C}$ and $\mathrm{T}=150^{\circ} \mathrm{C}$ temperatures.

The room temperature isotherm curve of the irradiated example was fitted to the $\mathrm{I}(\mathrm{t})=\mathrm{I}_{01} \exp (-$ $\left.\mathrm{k}_{1} \mathrm{t}\right)+\mathrm{I}_{02} \exp \left(-\mathrm{k}_{2} \mathrm{t}\right)$ shaped function and the fit parameters were found as; $\mathrm{I}_{01}=386.50 \pm 61.17$, $\mathrm{k}_{1}=1.3720 \pm 0.6085, \quad \mathrm{I}_{02}=2435.24 \pm 37.78$, $\mathrm{k}_{2}=0.0010 \pm 0.0006$ with correlation coefficient $\mathrm{R}^{2}=0.95$. As observed in the annealing process at $50{ }^{\circ} \mathrm{C}$, there are a short-lived unstable radical and a long-lived stable radical in sample. Room temperature lifetime of these radicals were determined as respectively, $\tau_{1}=0.729 \pm 0.324$ day and $\tau_{2}=1000 \pm 600$ day. As clearly seen, the life of the stable radical is quite long.

In all kinetic studies performed, $\mathrm{g}=2.0047$ signal in natural and irradiated coffee samples exhibited different behaviors and irradiated specimens could be distinguished by kinetic measurements. 


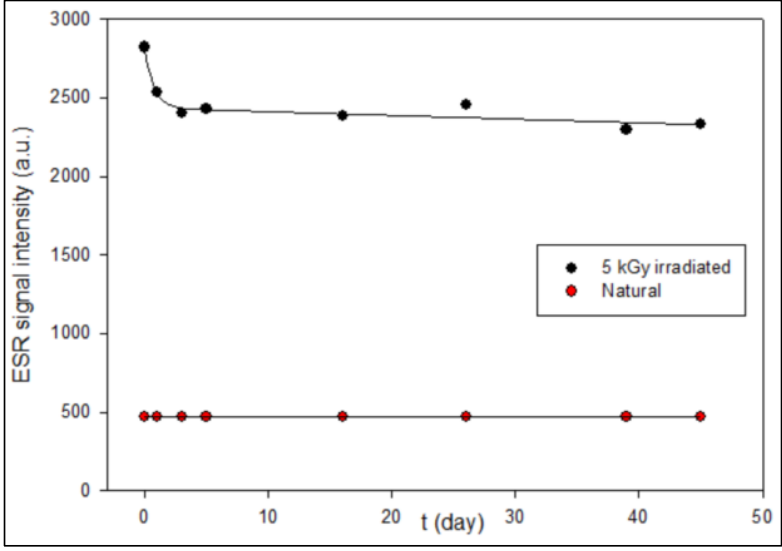

Figure 7. Room temperature kinetic behavior of $g=2.0047$ signal for natural and $5 \mathrm{kGy}$ irradiated samples.

In this study, the results obtained by ESR analysis of natural and irradiated coffee beans can be summarized as follows:

- It has been determined that radiation sensitive short-lived and long-lived paramagnetic centers are formed in the magnetic field region which are same that of radical formed in natural specimen, so the signals belonging these paramagnetic centers overlap and, form an envelope.

- It was observed by the kinetic measurements that the radiation sensitive paramagnetic center with the $\mathrm{g}$ value 2.0047 in coffee beans, was stable and did not completely disappear at $50{ }^{\circ} \mathrm{C}$ annealing temperature and, fairy stable at room temperature. The reason for the stability is that the coffee bean has a hard structure, which gives an advantage in terms of signal detectability or stability with respect to other foods containing cellulose.

- While the presence of this signal in the natural sample can be thought that it may limit its use as radiation dosimetry, it is shown that the signal has quite different kinetic property for natural and irradiated specimens. Thus, the discriminability of natural and irradiated specimens by kinetic studies indicates that the signal can be used in irradiated food detection and as a radiation dosimeter for the investigated dose range.

\section{REFERENCES}

[1] Zavoisky E., Spin Magnetic Resonance In Paramagnetic Substances, J.Phys. (USSR), 9, (1945) 245-7.

[2] Weil J.A., Bolton J.R., Wertz J.E., Electron Paramagnetic Resonance Elementary Theory and Practical Applications, John Wiley\&Sons, Inc., New York, 1994.

[3] Ikeya M., New Applications of Electron Spin Resonance Dating, Dosimetry and Microscopy, World Scientific Pub. Co. Pte. Ltd., 1993.

[4] Shukla A.K., Electron Spin Resonance in Food Science, Elsevier Academic Press, 2016.

[5] Nair P., Sharma A. Food Irradiation. Encycl. Agric. Sci., 2 (1994) 293-303.

[6] Thomas P., Control of Post-harvest Loss of Grains, Fruits and Vegetables by Radiation Processing. In Irradiation for Food Safety and Quality; Loaharanu P., Thomas P., Eds., Technomic Publishing: Lancaster, PA., 1999.

[7] Lacroix M. and Ouattara B., Combined Industrial Processes with Irradiation to Assure Innocuity and Preservation of Food Productsa Review. Food Research International, 33, (2000) 719-724.

[8] Loaharanu P., Irradiated Foods 5th ed., American Council on Science and Health, New York, 2003.

[9] Raffi J. and Stocker P., Electron Paramagnetic Resonance Detection of Irradiated Food Stuffs. Applied Magnetic Resonance, 10, (1996) 357-373.

[10] Raffi J., Yordanov N.D., Chabane S., Douifi L., Gancheva V., Ivanova S., Identification of Irradiation Treatment of Aromatic Herbs, Spices and Fruits by Electron Paramagnetic Resonance and Thermoluminescence, Spectrochimica Acta Part A, 56 (2000) 409-416.

[11] Korkmaz M., Polat M., Radical Kinetics and Characterization of the Free Radicals in Gamma Irradiated Red Pepper. Radiation Physics and Chemistry, 62 (2001) 411-421.

[12] Polovka M., Brezeva V., Simko P., EPR Spectroscopy: A Tool to Characterize Gamma-Irradiated Foods, Journal of Food and Nutrition Research, 46, 2 (2007) 75-83.

[13] Polat, M., Korkmaz, M., Detection of Irradiated Black Tea (Camellia sinensis) and Rooibos Tea (Aspalathus linearis) by ESR Spectroscopy. Food Chemistry, 107 (2008) 956-961. 
[14] Çam S.T., Engin B., Identification of Irradiated Sage Tea (Salvia officinalis L.) by ESR Spectroscopy. Radiation Physics and Chemistry, 79 (2010) 540-544.

[15] Sezer M.O., Kaplan N., Sayin U., ESR Analysis of Natural and Gamma Irradiated Coriander (Coriandrum sativum L.) Seeds, Radiation Effects and Defects in Solids, 172, 11-12 (2017) 815-823. 